\title{
Get in with a Foreigner: Consumer Trust in Domestic and Foreign Banks
}

\author{
Werner Bönte ${ }^{1,2,3}$, Ute Filipiak ${ }^{4} \&$ Sandro Lombardo ${ }^{1}$ \\ ${ }^{1}$ Schumpeter School of Business and Economics, University of Wuppertal, Germany \\ ${ }^{2}$ Jackstädt Center of Entrepreneurship and Innovation Research, University of Wuppertal, Germany \\ ${ }^{3}$ Institute for Development Strategies, School of Public \& Environmental Affairs, Indiana University, USA \\ ${ }^{4}$ Courant Research Centre Poverty Equity and Growth, Georg-August University of Göttingen, Germany \\ Correspondence: Ute Filipiak, Courant Research Centre Poverty Equity and Growth, Georg-August University \\ of Göttingen, Germany. E-mail: u.filipiak@uni-goettingen.de
}

Received: March 22, 2017

Accepted: April 27, 2017

Online Published: May 5, 2017

doi:10.5539/ijef.v9n6p38

URL: https://doi.org/10.5539/ijef.v9n6p38

\begin{abstract}
Prior research suggests that trust plays an important role in an individual's decision to participate in financial markets. This paper focuses on potential customers in retail banking markets and empirically investigates their trust in foreign banks and domestic banks. We argue that differences in customer trust can be related to three factors, namely bank-specific characteristics, individual characteristics of the potential customer and characteristics of the institutional environment. Using a large survey on the savings patterns of Indian households, we find that potential retail banking customers in India are less likely to trust foreign banks with their money than private Indian banks. However, our results also suggest that highly educated Indians using information sources such as the Internet, radio or newspaper, tend to have more confidence in foreign banks than in private Indian banks. Moreover, in regions with either more foreign bank branches or higher corruption levels the likelihood of consumers trusting Indian private banks more than foreign banks is lower than in other regions.
\end{abstract}

Keywords: trust, banking, India

\section{Introduction}

Consumer trust is of crucial importance for the development of financial markets, since trust influences the investment decisions of customers of financial services (Guiso et al., 2004, 2008; Balloch et al., 2015; Grabowski, 1998), and plays an important role in retail banking as well. A consumer's perception of the trustworthiness of a retail bank, i.e. its perceived reliability and fairness, may be a key factor for the consumer's decision to establish a long term relationship with the bank.

This study examines the variation in consumer trust by the type of bank. More specifically, it deals with the difference between consumers' trust in foreign banks and consumers' trust in domestic banks. For potential customers who know foreign and domestic banks, but are not customers of these types of banks as yet, it may make a difference whether they deposit their money with a domestic or foreign bank.

Potential customers' perception of a bank's trustworthiness might be an issue particularly in emerging economies where the number of individuals with savings is increasing and where investor protection tends to be still lower than in developed economies. In fact, very few people in emerging economies are investing their money with a foreign bank, although foreign banks have tried to expand their businesses to serve depositors in emerging economies. A lack of trust in foreign firms may be a key driver of relational hazards that may constitute a disadvantage for foreign firms resulting in a lower efficiency of foreign firms relative to domestic firms (Ataullah \& Le, 2004; Denk et al., 2012). If potential retail banking customers had more confidence in domestic banks than in foreign banks, the latter might need to put relatively more effort in establishing a customer relationship which would result in relatively higher costs.

This paper empirically investigates whether differences between potential customers' trust domestic and foreign banks exists. Moreover, it examines three factors that may explain these differences, namely bank-specific 
characteristics, individual characteristics of the potential customer and characteristics of the institutional environment in customers' trust in foreign and domestic banks.

To do so, we focus on retail banking in India. For several reasons India is appropriate to examine differences in consumer trust in domestic and foreign banks. First, India allows for studying the trust of potential customers in domestic and foreign banks, i.e. individuals who know these types of banks but are not customers as yet. While India deregulated its financial markets in 1990 and a retail banking market has developed, many households still do neither have savings accounts at private Indian banks nor at foreign banks. In contrast, in developed economies almost all people have some personal experiences with banks since most people already have a bank account. However, personal experience may result in a reverse causality problem as an established relationship with a certain type of bank tends to influence the level of trust in this type of bank. We exclude all individuals who have a bank account at a domestic private bank or a foreign bank, and focus instead on potential retail banking customers. By doing so, we avoid the potential bias caused by endogeneity that may arise from reverse causality. Second, the level of corruption in India is relatively high (Note 1). A high level of political and institutional corruption may increase the relevance of consumer trust in financial institutions (Hakhverdian \& Mayne, 2012). Moreover, Indian states show a lot of variation with respect to the level of corruption. This variation allows us to investigate of the relation between corruption and potential costumers' trust. Third, although India deregulated its financial markets, the regulatory framework was still very restrictive for foreign banks in the past thirty years. For instance, foreign banks were not allowed to open their bank branches in preferred locations but they were directed to open them in so-called priority sectors in the rural regions of India, as soon as a given number of branches was reached in urban areas. A lower presence of foreign banks compared to domestic banks, however, may lead to differences in potential customers' trust in these financial institutions. This regulation leads to a variation in the ratio of foreign banks to domestic private banks among Indian states and allows us to investigate the influence of these differences on potential retail banking customers' trust.

We make use of a unique data set that comprises detailed information about potential customers of domestic and foreign banks in India. Our data is obtained from the National Data Survey on Saving Patterns of Indians (NDSSP) conducted at the request of the Indian Ministry of Finance in 2004-2005. An important advantage of this data is that the respondents report, how much trust they have in different types of bankes which allows us to investigate potential customers trust in domestic and foreign banks. Hence, we are able to extend previous studies on participation in financial markets that used general trust measures (Guiso et al., 2008; Porta et al., 1997). We link this data set with additional data obtained from official sources, e.g. on the number of domestic private and foreign bank branches per Indian states and the level of corruption at the state-level.

This paper makes several relevant contributions to the existing literature. First, to the authors' best knowledge, this is the first study that empirically investigates the differences between potential customers' trust in domestic and foreign banks. Our results suggest that foreign banks in India face a lack of customer trust, which implies that they tend to be disadvantaged in the Indian retail banking market. Second, we also contribute to previous research investigating the relationship between trust and participation in financial markets. While prior studies mainly used general trust measures (Guiso et al., 2008; Porta et al., 1997), we make use of trust measures reflecting trust in certain types of financial institutions, namely domestic and foreign banks. Third, we contribute to the literature by examining the factors influencing trust differences. In particular, we discuss how characteristics of domestic and foreign banks, individual characteristics of potential customers and the institutional environment may influence a potential customer's trust in these financial institutions.

The remainder of the paper is organized as follows. The next section discusses the potential differences between consumer trust in domestic banks and consumer trust in foreign banks. The data source and the measurement of variables are described in Section 3. Descriptive statistics and the results of the econometric analysis are presented in section 4, Section 5 provides a Discussion and Section 6 concludes.

\section{Consumer Trust in Domestic and Foreign Banks}

Consumer trust in a bank is needed to attract new customers in particular in developing countries where financial market participation is still low (Honohan, 2008). A potential retail banking customer may never become an actual customer without a certain level of trust in the respective bank. Hence, consumer trust is of crucial importance in retail banking and building consumer trust is a major challenge for banks. In this study, we focus on potential retail banking customers, defined here as individuals who do not have a bank account but who have sufficient income to build savings and who also have savings to invest. We argue that potential retail banking customers' trust in domestic banks may differ from their trust in foreign banks.

The conceptual framework of our investigation refers to the theoretical model proposed by Guiso et al. (2008). 
Guiso et al. (2008) show theoretically how trust can affect the portfolio decision of an investor. In their model, an investor can choose between a safe asset with a certain safe return and a risky asset with an uncertain return. The investor assesses the risk as the probability that the firm in which he intends to invest might cheat. If the complementary probability called "trust" weighted with the gain from investment exceeds the assessed weighted loss probability that a bad outcome occurs, the individual will invest or, if not, will stay away from the risky investment. The investor thus intends to maximize her utility by choosing the optimal share of investment in these two assets by evaluating a certain risk of losing the amount invested in the risky asset. Since the model assumes that potential investors are able to assess their trust in different risky assets (firms) independently, this implies asset-specific trust levels. Therefore, only investors with a sufficiently high level of trust will invest in the stock market. Likewise, it can be argued that in the context of retail banking, potential retail banking customers may be willing to place their money with a bank, incurring the risk of losing money if the bank cheats, or they may not be willing to become a customer of the bank and keep their money in their possession without any return (safe asset). We argue that a bank's perceived trustworthiness depends on the characteristics of the respective bank, the individual characteristics of the potential customer and that it may also depend on the institutional environment.

The characteristics of the bank that affect potential customers' trust in the bank are, for instance, the financial services they provide or their way of managing risks. Consequently, customer trust in banks may be bank-specific and could therefore differ between banks. Moreover, different groups of banks share certain characteristics and thus potential customers' trust may also vary between different types of banks. We argue that potential retail banking customers may distinguish between domestic banks and foreign banks. For instance, corporate cultures of foreign banks, as well as the services offered, may differ from domestic private banks because the activities of foreign banks are usually controlled by foreign headquarters. There is also broad support for the fact that investors are more likely to make an investment when it is geographically nearby (Coval \& Moskowitz, 2001; Huberman, 2001; Ivkovic \& Weisbenner, 2005) and foreign bank branches are often not as widespread as domestic banks. On the other hand, foreign banks may originate from countries where financial markets are better developed than the financial market of the host country. Individuals may therefore expect that the probability of a negative outcome of a planned investment might be higher for domestic banks. Moreover, in countries where the level of corruption is very high, domestic banks might be perceived as more corrupt and less trustworthy than foreign banks.

These considerations determine the willingness of potential retail banking customers to place their money with domestic banks or with foreign banks. Customers take into account that the return of their invested money might be low or that the customer might even lose some or all of their investment. Of course, potential customers may also be convinced that it is the best option neither to become a customer of a domestic bank nor a customer of a foreign bank. Hence, the characteristics of domestic banks and foreign banks influence potential retail banking customers' overall degree of confidence, which may ultimately affect potential customers' decision to place their money with these types of banks.

A financial institution's perceived trustworthiness may further depend on the individual characteristics of the potential customer. Individuals differ in their individual characteristics and therefore the perceived trustworthiness of a financial institution may vary among potential customers of financial services. Individuals may differ in their risk attitude, education levels, general trust in financial institutions, but also in their way to gather information e.g. they may use different information sources.

Individuals who regularly use information sources, such as the Internet or the newspaper, may also be better informed on the practices of financial institutions. Financial institutions use different channels to advertise their products and to attract new customers (Claessens et al., 2002). Furthermore, the use of information sources could also help in bridging the barriers caused by the physical distance to a bank. Petersen and Rajan (2002), for instance, find that distances between firms and their lenders have even increased over the past years in the US, and argue that this may be driven by the revolution in information and communication technologies. Consumers of financial products, who use different information sources frequently, might be better able to assess the distribution of future payoffs of a planned investment with either a foreign or domestic bank, and the probability of a negative outcome might be lower.

Nevertheless, a potential investor needs to understand the information that financial institutions provide on their products or services. Therefore, another important determinant for explaining trust differences between foreign and domestic banks is the investor's level of education. Campbell (2006) provides empirical evidence that poorer and less educated households avoid financial transactions for which they feel unqualified. Hence, a given level of an individual's uncertainty resulting from a lack of financial knowledge, may negatively affect an 
individual's trust in financial institutions. Individuals with a very low educational background may trust domestic banks more than foreign banks because the former are often more familiar to potential customers. Similarly, individuals with a higher education may be more likely to trust a foreign bank more than a domestic private bank because they might be better able to assess the practices of a domestic and foreign institution, and therefore might have a better idea of which bank is more reliable compared to individuals with a lower education (Hakhverdian \& Mayne, 2012).

Individuals who differ in their risk attitude may have different levels of trust in financial institutions as well. In their theoretical model of stock market participation Guiso et al. (2008) show that two outcomes are possible if investors are risk averse. First, a risk averse investor may try to get benefits from diversifying into two stocks if losing the money through cheating in at least one stock occurs. Second, a risk averse investor can also diversify his money with respect to the expected idiosyncratic risks. Then, they will invest in the stock they consider to be less affected by these idiosyncratic risks (Guiso et al., 2008). Following this kind of reasoning, one can therefore argue that on the one hand risk averse individuals assess the probability of losing their money when investing in both types of banks equally. Consequently, their level of trust in domestic and foreign banks would be similar. However, risk averse individuals who fear idiosyncratic risks may trust a foreign bank more than a domestic bank, because they may be less affected by domestic market risks or other shocks since they are often strongly controlled by their foreign headquarters.

Finally, potential customers' trust in domestic and foreign banks may also be determined by the institutional environment. In the context of retail banking, consumer trust depends on objective characteristics of the financial system and spatial and cultural differences among individuals and banks (Guiso et al., 2008, 2009). In economies where the legal system is weak and property rights or the enforcement of contracts are not guaranteed, incentives for financial activities are low (Chinn \& Ito, 2006). Empirical evidence suggests that educated individuals are more trusting in less corrupt societies, and less trusting when their environment is considered corrupt (Hakhverdian \& Mayne, 2012). However, in many emerging countries the level of corruption is still remarkably high and public institutions often do not guarantee investors protection. Thus, the characteristics of the institutional environment may negatively affect an individual's trust in a financial institution if the perceived risk of losing their money increases, or on the other hand, reduce the perceived risk of losing the money when investor protection is high.

\section{Data}

\subsection{Source}

For our analysis, we used data from the National Data Survey on Saving Patterns of Indians (NDSSP), which is an overall Indian survey that is comprised of comprehensive information on the saving behavior of Indian households (see also Bönte \& Filipiak, 2012). This data set contains information on the trust for different bank types as well as rich information on Indian households. Although the NDSSP covers 40,862 household heads, the final sample in our econometric analysis consists of 11,708 observations. We restrict our analysis to a sub-sample of potential customers of private Indian banks and foreign banks. First, we focus on households with positive savings as they are potential customers who possess money that can be used for making financial investments. Second, we focus on households that do not have an account with an Indian private bank nor a foreign bank. In our econometric analysis we also use data obtained from the Reserve Bank of India. In addition to the NDSSP data, official RBI data on the number of branches of foreign banks, as well as the number of branches of private Indian banks at the Indian state level, is used.

\subsection{Measurement of Variables}

\subsubsection{Trust}

\section{1) Trust in Domestic and Foreign Banks:}

In the NDSSP survey a household head's trust in banks is measured by the question "What is your overall degree of confidence with the following financial institutions?". Several financial institutions were listed (e.g. National Banks, Indian private banks, and foreign banks) and the respondent could choose between five eligible answers ranging from one to five, being: (1) "I would definitely trust them with my money", (2) "I might trust them with my money", (3) "I would not like to trust them with my money", (4) "I would definitely not trust them with my money", and (5) "Don't know about this type of institution". From our econometric analysis we exclude all households that answered that they do not know Indian private banks or foreign banks.

2) Differences between Trust in Foreign and Private Banks

In order to investigate the differences in consumer trust in both type of banks, we use the aforementioned trust 
variables to compute a new variable Trust Difference. This variable consists of three categories. It takes the value of 1 if a respondent scores higher on trust in private Indian banks than on trust in foreign banks. For instance, the variable takes the value of 1 when a respondent states that they would definitely trust an Indian private bank with their money (score $=4$ ), but reports that they would not trust a foreign bank with their money (score=2). The variable takes the value of 2 if the trust scores of private Indian banks and foreign banks are identical and the variable takes on the value of 3 if a respondent scores higher on trust in foreign banks than on trust in private Indian banks.

\subsubsection{Explanatory Variables}

Financial Instruments: The NDSSP data provides information on individuals possessing an ATM card. The variable "ATMCard" is one if the respondents states that he has an ATM card at any financial institution, and zero if not. The respondents were also asked whether they possess a credit card and could answer with yes or no. The dummy variable "CreditCard" takes on the value of one if the respondent states that they have a credit card and zero otherwise.

Income: Private banks may have a target clientele that are often individuals with a certain level of income. The NDSSP dataset is comprised of information on individuals' total earnings from the primary and secondary occupation of the respondent during the last 12 months as well as other sources of incomes, e.g. rents or remittances. Moreover, respondents report their annual expenditures for food and groceries, real estate costs, education expenses, medical expenses or repayments of loans and others. The variable used to control for a certain investment potential, is the amount that the respondent has left after computing income minus expenditure.

Education: The education level of the respondent is considered by using twelve education dummy variables ranging from "illiterate" to "postgraduate and above", where illiterate is our reference category. Moreover, our dataset comprises information on the respondent's knowledge of the English language. We consider this by including a dummy variable that takes on the value one if the respondent is able to read, speak or write English. This is particularly important, because information about financial matters provided by foreign banks might be in English as opposed to the local language or Hindi.

Trust National Banks: In India most of the banks are still government owned. Nationalized Banks are very wide spread in India and offer deposit guarantees for investors. Moreover, national banks are among the most trusted of the existing financial institutions. We therefore take into account the respondent's level of trust in national banks. The variable "TrustNB" takes on the value one if the respondent answers that he would definitely trust a national bank with his money, or if he might trust a specific financial institution with money and zero otherwise.

Risk aversion: An individual's risk attitude might not only influence their decision to make an investment at a bank, but it may also affect an individual's trust in a financial institution. In order to take this into account, we employ the variable "risk aversion", which is measured using a lottery-type question. The interviewee has to make a hypothetical investment of 1000 rupees and can choose between three alternative investments. In the first choice, a deposit of Rs. 1000 may turn into 2000 Rs. after one year or the investor may only get Rs. 500 back. In the second choice, the deposit may grow to be up to Rs. 1200 or the investor may lose some of the money and get Rs. 800 back. In the third choice, the deposit may grow to be Rs. 1050 without any loss. The dummy variable for risk attitude takes on the value of one if an interviewee opts for the third choice and zero otherwise. Hence, this indicator may reflect an individual's risk aversion, since only the third choice guarantees a positive return, whereas the returns are uncertain in the first and the second choices.

Information sources: Although foreign, as well as private banks, are still not very widespread in India, geographical distances can be bridged by the use of modern communication technologies such as TV, the Internet or a newspaper. Therefore, we control for the regular and irregular use of these communication technologies. Furthermore, we control for several other individual characteristics that may influence trust in domestic and foreign banks (Note 2).

Regional Characteristics: Trust in banks may be strongly related to an individual's perceived level of institutional corruption, which might be very relevant to consider when investigating a developing country such as India. We therefore use the "Corruption Perception Index" (CPI) at the Indian state level, which is provided by Transparency International and reflects an individual's perceived corruption of different public institutions in India. For India, the Index varies between 240 and 695 among the Indian states, and the average is 477 . The higher the value, the greater the perceived corruption at the institutional level. The variable "high-corruption", takes on the value of one when the respondent lives in a state where the corruption perception index is high, which means that it is above the average level. Unfortunately, the data is only available for 20 Indian states. 
Since the NDSSP Data considers 25 Indian states, including the CPI leads to a reduced sample size. Furthermore, we consider the share of foreign banks to private banks per Indian state "Foreign Bank to Private Bank Ratio" as additional variable (Note 3). We also include the Gross Domestic Product per capita GDP at the Indian state level as an additional control variable. The variables, GDP and CPI, as well as the foreign bank to private bank ratio, are used for the years 2004 and 2005 in which the NDSSP survey was conducted.

\section{Empirical Results}

\subsection{Difference between trust in domestic banks and trust in foreign banks}

Although India liberalized its financial market at the beginning of the 1990s, retail banking is still underdeveloped in India. Our dataset confirms that in India, the proportion of people having a savings account at a bank is much lower than in developed economies. Table 1 shows that only about 52 percent $(17,438$ respondents) of the interviewees report having a bank account and most of them $(9,747)$ have an account at a national bank. Moreover, only 7 percent $(1,215)$ of the respondents report that they have a savings account at an Indian private bank. Only 36 respondents $(0.21$ percent) report that they have an account at a foreign bank, emphasizing that private banking is still an issue in India. Customers of financial services might not be very familiar with products that private financial institutions offer. This problem is likely to be even more severe for foreign banks. Conversely, financial products and services provided by nationalized banks are common and frequently used by individuals.

Table 1. Bankaccount Holders in the NDSSP-Data

\begin{tabular}{lccr}
\hline Bankaccount & Yes & No & Total \\
\hline & 17,438 & 15,989 & 33,427 \\
& $(52.17)$ & $(47.83)$ & $(100.00)$ \\
\hline Account Holders & & & 17,438 \\
National Bank & 9,747 & 7,691 & $(100.00)$ \\
& $(55.90)$ & $(44.10)$ & 17,438 \\
Indian Private Bank & 1,215 & 16,223 & $(100.00)$ \\
& $(6.97)$ & $(93.03)$ & 17,438 \\
Foreign Bank & 36 & 17,402 & $(100.00)$ \\
& $(0.21)$ & $(99.79)$ & 17,438 \\
Other Banks & 6,440 & 10,829 & $(100.00)$ \\
\hline
\end{tabular}

Note. Table 1 reports the number of bank account holders in the NDSSP Dataset. Out of 33,427 individuals, 17,438 respondents report that they have a bank account at a financial institution. Among those respondents who possess a bank account, 9,747 report having an account with a national bank, 1,215 report having a bank account with an Indian private bank, 36 respondents report having a bank account with a foreign bank. 6,440 respondents have a bank account with another type of bank, e.g. a regional rural bank or a cooperative bank. Numbers in parentheses denote the relative frequencies which sum up to 100 in total.

Figure 1 reports the percentaged shares of trust in national banks, domestic private banks and foreign banks. The figure shows that most of the sample respondents ( 93.87 percent) state that they would definitely trust a national bank with their money. When it comes to domestic private banks and foreign banks, most of the sample respondents say that given a choice, they would rather not trust them or that they would definitely not trust them with their money. The share of those respondents who state that they would definitely trust a domestic private bank or a foreign bank stands at 13.16 percent and 6.54 percent respectively, remarkably lower in comparison to national banks. The difference between trust in national banks and trust in private banks might be explained by the fact that national banks are backed by the Indian government, which implies that customers of national banks do not face the risk of losing their money. In contrast, bankruptcy is an issue for both types of banks. We will therefore focus on the comparison between trust in private Indian banks and foreign banks. These descriptive statistics show that customer trust in foreign banks and domestic private banks may be an issue for potential customers of these banks in India. However, around 44.96 percent do not know of a foreign bank and 16.53 percent of a domestic private bank. These don't-know-responses are excluded from the empirical analysis. 


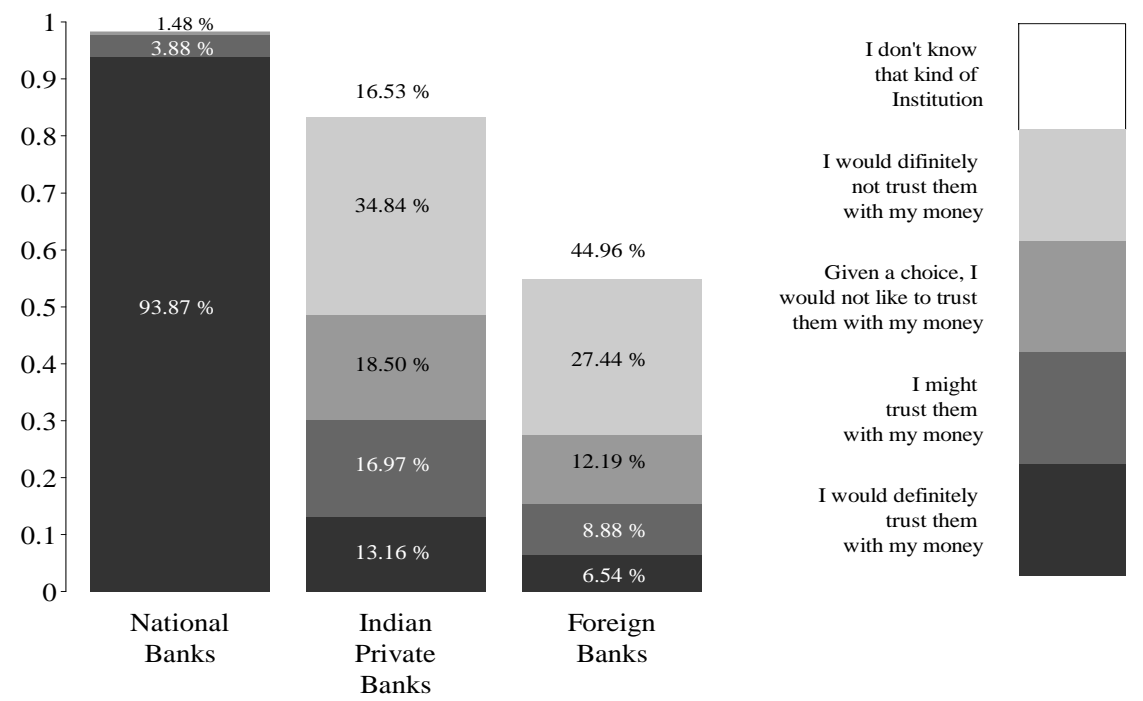

Figure 1. Customer trust in banks

Note. Figure 1 shows the percentage share of different levels of trust in different financial institutions in India 93.87 percent of the sample respondents state that they would definitely trust a national bank With their money, 13.16 percent state that they would definitely trust a private Indian bank with their money and 6.54 percent state that they would definitely trust a foreign bank with their money.

Figure 2 shows the share of respondents that have more confidence in private Indian banks than in foreign banks, the share of respondents having the same level of trust in private Indian banks and foreign banks, and the share of respondents who trust foreign banks more than private Indian banks. This figure thus, focuses on relative trust and not on the absolute level of trust. The left pie chart presents these shares for the total sample of respondents. More than 58 percent of the respondents report identical levels of trust for both types of banks. Around 30 percent of the respondents would trust private Indian banks more with their money than foreign banks and around 11 percent have more confidence in foreign banks than in private Indian banks.

In addition, Figure 2 reports these shares for the sample of respondents who do not have savings account at an Indian private bank nor a foreign bank, the sample of respondents who have an account at an Indian private bank, and the sample of respondents who have an account at a foreign bank. Among the respondents that have a bank account at an Indian private bank, the share of individuals trusting foreign banks more than private Indian banks is 10 percent, which is close to the share reported for the total sample. Among the individuals that have a bank account at a foreign bank, the share of individuals that have more confidence in foreign banks than in private Indian banks is 36 percent. This shows that foreign banks are more trusted than private Indian banks by individuals who have financial experience with foreign banks. Similarly, 38 percent of individuals who have an account at an Indian private bank trust private Indian banks more than foreign banks.

However, the number of individuals who have a bank account at a foreign bank is very low and the direction of causality is unclear. Experiences with a foreign bank or a domestic private bank may lead to more trust in the respective bank, but trust may also result in the opening of a savings account. In our empirical analysis, we will therefore focus on potential customers, i.e. individuals who do not have accounts at private Indian banks nor foreign banks but who know these financial institutions. 

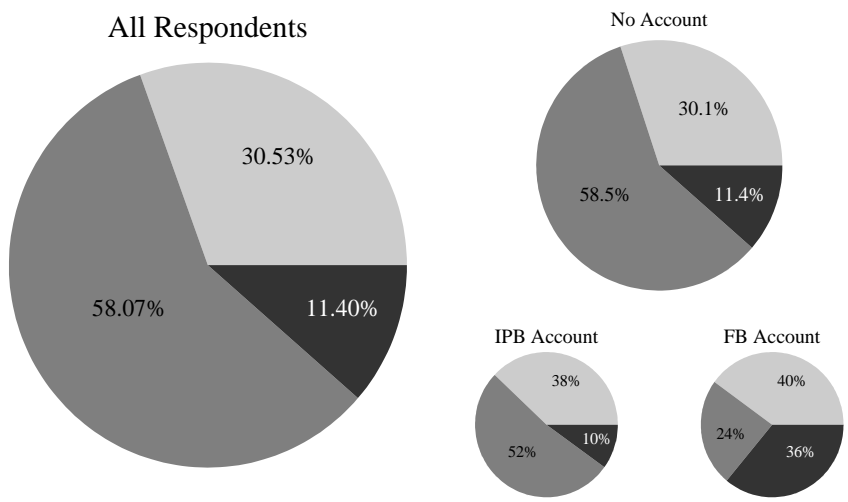

More Trust in Foreign Banks

Equal Trust in Foreign and Indian Private Banks

Less Trust in Foreign Banks

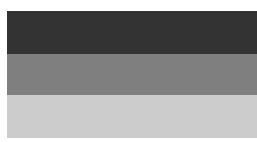

Figure 2. Trust-differences in banks

Note. Figure 2 shows the differences in consumer trust among Indian private and foreign banks. First, we consider all sample respondents (left chart). Second, we build different sub-samples of those respondents who do not have a bank account at an Indian private bank and at a foreign bank. We compare it to those who have an account at an Indian private bank, as well as to those who have an account at a foreign bank (right charts). The percentage share of respondents, who state that they would trust a foreign bank more than a domestic private bank, is the lowest in three of four pie-charts, except when employing the sample of respondents who have a bank account at a foreign bank.

\subsection{Determinants of Trust Differences}

Although we focus on individuals who do not have a bank account at a foreign bank nor an Indian private bank, people might have a bank account at another kind of bank. People who have a bank account may also use credit or ATM cards. Table 2, reports that 4 percent of our sample respondents have a credit card, and 10 percent possess an ATM card. Hence, only a few individuals hold financial relationships with banks or other financial institutions using these financial instruments. Furthermore, Table 2 shows that 17 percent of the sample respondents have a middle school education, 23 percent have a high school education, 11 percent have a higher secondary education, 14 percent have graduated from university and 55 percent report that they can either, read, write or speak English. 74 percent of the respondents can be considered being risk averse. The number of female respondents in our final sample is 8 percent, which is very low. Moreover, 14 percent of the sample respondents are self-employed in the formal sector and 32 percent are employed in white collar jobs. About 57 percent of the respondents use information sources such as the Internet and newspapers every day. Among the regional characteristics, Table 2 shows that 38 percent of the respondents live in a state where the perceived level of institutional corruption is very high.

Table 2. Summary statistics for explanatory variables

\begin{tabular}{|c|c|c|c|c|c|}
\hline & Observations & Mean & Standard Deviation & Min & Max \\
\hline \multicolumn{6}{|l|}{ Financial Instruments } \\
\hline CreditCard & 11708 & 0.042 & 0.200 & 0 & 1 \\
\hline ATMCard & 11708 & 0.104 & 0.305 & 0 & 1 \\
\hline \multicolumn{6}{|l|}{ Trust and Risk } \\
\hline Trust in National Banks & 11708 & 0.992 & 0.090 & 0 & 1 \\
\hline Risk Averse & 11708 & 0.738 & 0.440 & 0 & 1 \\
\hline \multicolumn{6}{|l|}{ Education } \\
\hline Literate no schooling & 11708 & 0.018 & 0.134 & 0 & 1 \\
\hline Less than primary & 11708 & 0.037 & 0.188 & 0 & 1 \\
\hline Primary school & 11708 & 0.094 & 0.291 & 0 & 1 \\
\hline Middle school & 11708 & 0.170 & 0.376 & 0 & 1 \\
\hline High school & 11708 & 0.235 & 0.424 & 0 & 1 \\
\hline Higher secondary & 11708 & 0.112 & 0.315 & 0 & 1 \\
\hline Technical diploma & 11708 & 0.026 & 0.159 & 0 & 1 \\
\hline Graduate & 11708 & 0.145 & 0.352 & 0 & 1 \\
\hline
\end{tabular}




\begin{tabular}{|c|c|c|c|c|c|}
\hline Professional degree & 11708 & 0.031 & 0.174 & 0 & 1 \\
\hline Post graduate & 11708 & 0.038 & 0.190 & 0 & 1 \\
\hline English & 11708 & 0.551 & 0.497 & 0 & 1 \\
\hline \multicolumn{6}{|l|}{ Personal Characteristics } \\
\hline Income & 11708 & 72.284 & 102.659 & 0.7 & 6400 \\
\hline Age & 11708 & 39.614 & 11.335 & 17 & 98 \\
\hline Female & 11708 & 0.080 & 0.271 & 0 & 1 \\
\hline Married & 11708 & 0.853 & 0.354 & 0 & 1 \\
\hline White Collar & 11708 & 0.318 & 0.466 & 0 & 1 \\
\hline Self Employed & 11708 & 0.140 & 0.347 & 0 & 1 \\
\hline \multicolumn{6}{|l|}{ Information Sources } \\
\hline Daily use of radio and TV & 11708 & 0.774 & 0.418 & 0 & 1 \\
\hline No use of radio and TV & 11708 & 0.075 & 0.264 & 0 & 1 \\
\hline Daily use of newspaper and Internet & 11708 & 0.575 & 0.494 & 0 & 1 \\
\hline No use of newspaper and Internet & 11708 & 0.220 & 0.414 & 0 & 1 \\
\hline \multicolumn{6}{|l|}{ Regional Characteristics } \\
\hline High Corruption (state level) & 11708 & 0.377 & 0.485 & 0 & 1 \\
\hline GDP p.c. (state level) & 11708 & 9.949 & 0.413 & 8.841 & 10.816 \\
\hline Ratio of Foreign Banks to Indian Banks & 11708 & 0.074 & 0.096 & 0 & 0.305 \\
\hline
\end{tabular}

Note. Table 2 reports the summary statistics for the explanatory variables that were used. Those respondents are considered who currently possess a savings account neither at a foreign bank nor at an Indian Private bank. Official data for Indian per state are given in Rupees (RS). The sample consists of 11,708 respondents.

The results of the multinomial logit regression are reported in Table 3 (Note 4). The dependent variable comprises three outcome categories. In the first category, respondents have more confidence in private Indian banks than in foreign banks (column 1). In the second category, the level of trust in private Indian banks does not differ from the level of trust in foreign banks (column 2), and in the third category, respondents have more confidence in foreign banks than in domestic banks (column 3) (Note 5). Table 3 does not report the estimated coefficients, but the average marginal effects, since the latter are easier to interpret and can be calculated for all three categories.

Among the characteristics of the respective bank, the table shows that the spatial presence of bank branches of foreign and private banks is very important for trusting domestic private banks and foreign banks. The results show that individuals who live in a state where the share of foreign banks relative to private Indian banks is high measured by the number of foreign banks divided by the number of private banks have a 9.8 percentage points lower probability of trusting a domestic private bank more than a foreign bank with their money, whereas these individuals have a 14 percentage points higher probability of trusting both financial institutions equally. The effects are statistically significant at the one and five percent levels.

Table 3 shows that among the individual characteristics of the potential customers, the level of education of the potential customer is very relevant when investigating differences in trust between private Indian banks and foreign banks. In the first row, Table 3 shows that individuals with a higher education level are less likely to trust a private Indian bank with their money in comparison to a foreign bank. This result is the opposite for the third row. This indicates that individuals with a higher level of education are more likely to trust a foreign bank than a private Indian bank with their money.

Moreover, the effects increase in their size as the education level increases. Individuals who have graduated from university, have an 8.7 percentage point higher probability of trusting a foreign bank more than a domestic private bank. For individuals with a professional degree, the effect is with 13.7 percentage points, even larger. On the other hand, being able to speak, read or write English, lowers the probability of trusting a foreign bank more than an Indian private bank by 2.3 percentage points, whereas this effect is not significant for the remaining two categories.

Among the variables reflecting a respondent's trust and risk attitude, trust in national banks is negatively related to trusting a foreign bank more than an Indian private bank, whereas the effect is positive but not statistically significant for trusting an Indian private bank more than a foreign bank with money. Nevertheless, by using trust in national banks as a regressor in our estimation, we take into account national banks as a benchmark as the latter are usually considered to be very reliable. Individuals who are rather risk averse are less likely to trust an Indian private bank more than a foreign bank. However, being risk averse increases the likelihood to trust both financial institutions equally by 2.5 percentage points. Among the use of information sources considered, the 
daily use of radio and TV, does not seem to be very relevant in explaining trust differences between domestic private and foreign banks, whereas reading the newspaper and using the Internet every day is related to a lower probability of trust in a domestic private bank more than a foreign bank, and to a higher probability, to trust a foreign bank more than a domestic private bank. In contrast, individuals who are not reading the newspaper or using the Internet at all are more likely to trust a domestic private bank more than a foreign bank with their money.

The institutional environment of the state where the respondent lives, may influence a potential customers trust in a domestic bank or in a foreign bank as well. Table 3 shows that individuals living in a state where the perceived level of institutional corruption is very high, have a 4.7 percentage points lower probability of trusting a domestic private bank more than a foreign bank. This is also positively related to trusting both types of financial institutions equally. Moreover, living in a state where the GDP per capita is relatively high, is associated with a higher probability of trusting a domestic private bank more than a foreign bank. Furthermore, living in a state where the share of foreign banks to domestic private banks is relatively high, is associated with a lower probability of trusting domestic private banks more than foreign banks.

We conducted several additional regressions to check the robustness of our results. For instance, we performed separate ordered Probit regressions for consumer trust in domestic private banks and foreign banks to account for the ordered structure of our trust variable or we included dummy variables to control for town-specific fixed effects. Although not reported here, various robustness checks confirm our main results (Note 6).

Table 3. Trust difference: foreign and private banks

\begin{tabular}{|c|c|c|c|}
\hline & (1) & $(2)$ & (3) \\
\hline \multicolumn{4}{|l|}{ Financial Instruments } \\
\hline \multirow[t]{2}{*}{ CreditCard } & -0.008 & -0.021 & $0.029^{*}$ \\
\hline & $(0.023)$ & $(0.025)$ & $(0.016)$ \\
\hline \multirow[t]{2}{*}{ ATMCard } & 0.008 & -0.015 & 0.007 \\
\hline & $(0.016)$ & $(0.017)$ & $(0.010)$ \\
\hline \multicolumn{4}{|l|}{ Trust and Risk } \\
\hline \multirow[t]{2}{*}{ Trust in National Banks } & 0.027 & 0.040 & $-0.067^{*}$ \\
\hline & $(0.046)$ & $(0.052)$ & $(0.040)$ \\
\hline \multirow[t]{2}{*}{ Risk Averse } & $-0.033^{* * *}$ & $0.025^{* *}$ & 0.009 \\
\hline & $(0.010)$ & $(0.011)$ & $(0.006)$ \\
\hline \multicolumn{4}{|l|}{ Education } \\
\hline \multirow[t]{2}{*}{ Literate no schooling } & 0.008 & -0.005 & -0.004 \\
\hline & $(0.034)$ & $(0.038)$ & $(0.027)$ \\
\hline \multirow[t]{2}{*}{ Less than primary } & $-0.065^{* * *}$ & 0.006 & $0.059 * *$ \\
\hline & $(0.024)$ & $(0.030)$ & $(0.026)$ \\
\hline \multirow[t]{2}{*}{ Primary school } & $-0.053^{* * *}$ & $0.049 * *$ & 0.004 \\
\hline & $(0.020)$ & $(0.023)$ & $(0.017)$ \\
\hline \multirow[t]{2}{*}{ Middle school } & $-0.069 * * *$ & $0.051 * *$ & 0.018 \\
\hline & $(0.018)$ & $(0.022)$ & $(0.017)$ \\
\hline \multirow[t]{2}{*}{ High school } & $-0.050 * *$ & 0.021 & 0.029 \\
\hline & $(0.020)$ & $(0.023)$ & $(0.018)$ \\
\hline \multirow[t]{2}{*}{ Higher secondary } & $-0.042^{*}$ & -0.015 & $0.057 * *$ \\
\hline & $(0.022)$ & $(0.027)$ & $(0.023)$ \\
\hline \multirow[t]{2}{*}{ Technical diploma } & $-0.060 * *$ & -0.019 & $0.079 * *$ \\
\hline & $(0.030)$ & $(0.038)$ & $(0.035)$ \\
\hline \multirow[t]{2}{*}{ Graduate } & $-0.070 * * *$ & -0.017 & $0.087 * * *$ \\
\hline & $(0.022)$ & $(0.027)$ & $(0.025)$ \\
\hline \multirow[t]{2}{*}{ Professional degree } & $-0.057^{*}$ & $-0.080 * *$ & $0.137 * * *$ \\
\hline & $(0.029)$ & $(0.038)$ & $(0.038)$ \\
\hline \multirow[t]{2}{*}{ Post graduate } & $-0.064 * *$ & -0.005 & $0.069^{* *}$ \\
\hline & $(0.027)$ & (0.034) & $(0.031)$ \\
\hline \multirow[t]{2}{*}{ English } & 0.0087 & 0.014 & $-0.023 * * *$ \\
\hline & $(0.012)$ & $(0.013)$ & $(0.008)$ \\
\hline
\end{tabular}




\begin{tabular}{|c|c|c|c|}
\hline \multicolumn{4}{|l|}{ Personal Characteristics } \\
\hline \multirow[t]{2}{*}{ Income } & $-0.012^{*}$ & 0.003 & $0.009 * *$ \\
\hline & $(0.007)$ & $(0.007)$ & $(0.004)$ \\
\hline \multirow[t]{2}{*}{ Age } & 0.000 & -0.000 & -0.000 \\
\hline & $(0.000)$ & $(0.000)$ & $(0.000)$ \\
\hline \multirow[t]{2}{*}{ Female } & $0.030 *$ & $-0.035 * *$ & 0.005 \\
\hline & $(0.017)$ & $(0.018)$ & $(0.011)$ \\
\hline \multirow[t]{2}{*}{ Married } & -0.008 & 0.011 & -0.003 \\
\hline & $(0.013)$ & $(0.014)$ & $(0.009)$ \\
\hline \multirow[t]{2}{*}{ White Collar } & 0.012 & -0.008 & -0.004 \\
\hline & $(0.011)$ & $(0.012)$ & $(0.007)$ \\
\hline \multirow[t]{2}{*}{ Self Employed } & -0.002 & -0.010 & 0.012 \\
\hline & $(0.014)$ & $(0.015)$ & $(0.009)$ \\
\hline \multicolumn{4}{|l|}{ Information Sources } \\
\hline \multirow[t]{2}{*}{ Daily use of radio and TV } & 0.006 & 0.002 & -0.007 \\
\hline & $(0.013)$ & $(0.014)$ & $(0.009)$ \\
\hline \multirow[t]{2}{*}{ No use of radio and TV } & -0.010 & 0.018 & -0.008 \\
\hline & $(0.020)$ & $(0.021)$ & $(0.014)$ \\
\hline \multirow[t]{2}{*}{ Daily use of newspaper and Internet } & -0.009 & -0.004 & 0.013 \\
\hline & $(0.012)$ & $(0.013)$ & $(0.008)$ \\
\hline \multirow[t]{2}{*}{ No use of newspaper and Internet } & $-0.047 * * *$ & $0.056 * * *$ & -0.010 \\
\hline & $(0.015)$ & $(0.016)$ & $(0.011)$ \\
\hline \multicolumn{4}{|l|}{ Regional Characteristics } \\
\hline \multirow[t]{2}{*}{ High Corruption (state level) } & $-0.047 * * *$ & $0.047 * * *$ & 0.000 \\
\hline & $(0.010)$ & $(0.010)$ & $(0.006)$ \\
\hline \multirow[t]{2}{*}{ GDP p.c. (state level) } & 0.018 & $-0.030 * *$ & 0.012 \\
\hline & $(0.012)$ & $(0.013)$ & $(0.008)$ \\
\hline \multirow[t]{2}{*}{ Ratio of Foreign Banks to Indian Banks } & $-0.098 * *$ & $0.14 * * *$ & -0.038 \\
\hline & $(0.047)$ & $(0.050)$ & $(0.032)$ \\
\hline Observed probabilities & 0.301 & 0.585 & 0.114 \\
\hline Predicted probabilities & 0.301 & 0.589 & 0.110 \\
\hline
\end{tabular}

Note. Table 3 reports the marginal effects at the mean using multinomial logit regression. Columns report the probability to trust a domestic private bank more than a foreign bank (1), to trust a domestic private bank and a foreign bank similarly (2), and to trust a foreign bank more than a domestic private bank (3). The number of observations is 11,708 . Standard errors are given in parentheses. ***, **, * denote significance at the $1,5,10$ percent level.

\section{Discussion}

While previous literature focuses on the role of customer trust for stock market participation (Guiso et al., 2008; Porta et al., 1997), our knowledge about customers' trust in the retail banking market in emerging countries is still limited. This paper empirically investigates potential retail banking customers' trust in domestic and foreign banks using data from Indian households. We examine the factors influencing trust differences between domestic private banks and foreign banks in India.

Our results show that potential retail banking customers in India are less likely to trust foreign banks with their money than private Indian banks indicating that a low level of customer trust-as a potential relational hazardexists for foreign banks in India. Hence, our study complements existing studies that investigate the supply-side in business banking, e.g. the lower efficiency of foreign banks relative to domestic banks (Ataullah \& Le, 2004; Denk et al., 2012). Although it has been assumed that a lack of trust is a key driver of relational hazards that may constitute a disadvantage for foreign firms resulting in a lower efficiency of foreign firms relative to domestic firms (Denk et al., 2012), differences between consumer trust in foreign banks and domestic banks have not been empirically investigated as yet. Our results show that this difference can be explained at least partly by three factors, namely by bank-specific characteristics, individual characteristics of the potential customer and characteristics of the institutional environment.

Our findings suggest that the presence of bank branches of domestic and foreign banks in a region plays a role in determining potential customers' relative levels of trust in domestic and foreign banks. An individual's probability of trusting domestic private banks more than foreign banks is negatively associated with a higher 
number of branches of foreign banks relative to the number of private Indian banks at the state-level. Potential customers of foreign banks who live in a region where the number of foreign banks is high, might be more familiar with, and have better knowledge of foreign banks. Since domestic private banks are not regulated to the same extend by the Indian government as foreign banks, this would imply that existing regulations that restrict especially the opening of new branches by foreign banks, tend to lead to a lower level of trust of potential customers in foreign banks, as compared to domestic banks.

Furthermore, this paper provides evidence that individual characteristics may explain trust differences in domestic private banks and foreign banks. Firstly, trust differences are related to the willingness to take risks. Potential customers, who are risk-averse have a higher probability of trusting both types of banks to the same extent, instead of having more trust in one type of bank. This might suggest that risk-averse individuals try to diversify the risk of being cheated and losing their money. Secondly, the level of education is relevant for the differences in trust. A higher level of education leads to a decrease in the probability of trusting a domestic bank, but increases the probability of trusting a foreign bank. Individuals with a higher level of education might be less affected by a "home bias" since they may have a greater ability to assess the financial services provided by foreign banks and domestic banks, as they might be better informed of the practices of foreign banks. Thirdly, the use of information sources affects differences in trust. Although the use of various information sources may be very relevant in providing information on financial institutions, only the daily use of the newspaper, as well as the daily use of the Internet, is relevant for trusting a foreign bank more than a domestic bank. Potential customers who use the Internet or read the newspaper daily may also get information about foreign banks and private banks and their current practices. This in turn may affect their level of trust respectively.

Finally, the institutional environment seems to be important as well. While in India the overall level of corruption is very high Indian states differ considerably with respect to the level of corruption. Our results suggest that potential customers living in an Indian state where the perceived institutional corruption is very high, are less likely to trust a domestic bank more than a foreign bank and that they have a higher probability of trusting both types of banks to the same extent. One possible explanation may be that potential investors may try to diversify perceived idiosyncratic risks of losing their money. Foreign banks might not be as strongly affected by local corruption issues as domestic banks and this may be anticipated by their potential customers.

These results may not only be relevant for retail banks aiming to establish a trust based relationship with their customers, but also for government policies. Recently, the Indian Prime Minister Narendra Modi has launched an initiative to help the poor by providing a bank account for every household. Many Indians have little access to financial services and this is also confirmed in our data. Only about 53 percent of the respondents report that they have a bank account and most of them have an account at a national bank, whereas only 7 percent of the respondents report that they have a savings account at a private Indian bank and the number of respondents having an account at a foreign bank is negligible. Hence, there is a large number of potential retail banking customers that do not have a bank account at a domestic private bank or at a foreign bank. In principle, potential customers might benefit from the market entry of foreign banks. For instance, studies show that investors tend to invest not only in local assets, but also in assets offered by foreign banks or companies, and this increases when markets are better integrated (Baele et al., 2007).

However, India's banking sector is still highly regulated and India still faces a high level of corruption. Hence, the regulation of market entry by the Indian government, corruption and the resulting lack of customer trust, may inhibit foreign banks from entering the market. This is a crucial point since foreign banks may also be very important for introducing financial innovation in emerging countries (Bauer et al., 2008). Moreover, our results might not only be relevant for India, but also for other emerging economies and developing countries with similar financial market characteristics.

\section{Conclusion}

Customer trust in financial institutions is highly relevant for the future market participation of potential customers as well as for the development of financial markets as a whole. From a theoretical point of view, it is unclear a priori whether potential retail banking customers have more confidence in domestic or foreign banks. Using a large scale survey on saving patterns of Indians, we find that potential retail banking customers in India are less likely to trust foreign banks with their money than private Indian banks. The results of a more detailed empirical analysis suggest that individuals' levels of trust in domestic and foreign banks are influenced by bank-specific characteristics, individual characteristics of the potential customer and characteristics of the institutional environment. Better knowledge about potential customers' trust in financial institutions and the determinants of trust can help policies and financial institutions to overcome obstacles to financial market 
participation that are rooted in a low level of consumer trust in financial institutions.

\section{References}

Ataullah, A., \& Le, H. (2004). Financial repression and liability of foreignness in developing countries. Applied Economics Letters, 11(9), 545-549. https://doi.org/10.1080/1350485042000263034

Baele, L., Pungulescu, C., \& Horst, J. T. (2007). Model uncertainty, financial market integration and the home bias puzzle. Journal of International Money and Finance, 26(4), 606-630. https://doi.org/10.1016/j.jimonfin.2007.03.007

Balloch, A., Nicolae, A., \& Philip, D. (2015). Stock market literacy, trust, and participation. Review of Finance, 19(5), 1925-1963. https://doi.org/10.1093/rof/rfu040

Bauer, C., Herz, B., \& Hoops, S. (2008). A cheap lunch for emerging markets: Removing international financial market imperfections with modern financial instruments. World Development, 36(9), 1514-1530. https://doi.org/10.1016/j.worlddev.2007.09.003

Bönte, W., \& Filipiak, U. (2012). Financial Literacy, Information Flows, and Caste Affiliation: Empirical Evidence from India. Journal of Banking \& Finance, 36(12), 3399-3414. https://doi.org/10.1016/j.jbankfin.2012.07.028

Campbell, J. Y. (2006). Household Finance. The Journal of Finance, 61(4), 1553-1604. https://doi.org/10.1111/j.1540-6261.2006.00883.x

Chinn, M. D., \& Ito, H. (2006). What matters for financial development? Capital controls, institutions, and $\begin{array}{lllll}\text { interactions. Journal of Development } & \text { Economics, } & \text { 81(1), }\end{array}$ https://doi.org/10.1016/j.jdeveco.2005.05.010

Claessens, S., Glaessner, T., \& Klingebiel, D. (2002). E-finance in emerging markets: Is leapfrogging possible? Financial Markets Institutions \& Instruments, 11(1), 1-125. https://doi.org/10.1111/1468-0416.00001

Coval, J. D. \& Moskowitz, T. J. (2001). The Geography of Investment: Informed Trading and Asset Prices. Journal of Political Economy, 109(4), 811-841. https://doi.org/10.1086/322088

Denk, N., Kaufmann, L., \& Roesch, J. F. (2012). Liabilities of foreignness revisited: A review of contemporary studies nd recommendations for future research. Journal of International Management, 18(4), 322-334. https://doi.org/10.1016/j.intman.2012.07.001

Grabowski, R. (1998). Development, markets and trust. Journal of International Development, 10(3), 357-371. https://doi.org/10.1002/(SICI)1099-1328(199805/06)10:3<357::AID-JID480>3.0.CO;2-W

Guiso, L., Sapienza, P., \& Zingales, L. (2004). The role of social capital in financial developement. The American Economic Review, 94(3), 526-556. https://doi.org/10.1257/0002828041464498

Guiso, L., Sapienza, P., \& Zingales, L. (2008). Trusting the stock market. The Journal of Finance, 63(6), 2557-2600. https://doi.org/10.1111/j.1540-6261.2008.01408.x

Guiso, L., Sapienza, P., \& Zingales, L. (2009). Cultural biases in economic exchange. The Quarterly Journal of Economics, 124(3), 1095-1131. https://doi.org/10.1162/qjec.2009.124.3.1095

Hakhverdian, A., \& Mayne, Q. (2012). Institutional trust, education, and corruption: A micro-macro interactive approach. Journal of Politics, (74), 739-750. https://doi.org/10.1017/S0022381612000412

Honohan, P. (2008). Cross-country variation in household access to financial services. Journal of Banking and Finance, 32, 2493-2500. https://doi.org/10.1016/j.jbankfin.2008.05.004

Huberman, G. (2001). Familiarity breeds investment. Review of Financial Studies, 14(3), 659-680. https://doi.org/10.1093/rfs/14.3.659

Ivkovic, Z., \& Weisbenner, S. (2005). Local does as local is: Information content of the geography of individual investors common stock investments. Journal of Finance, 60(1), 267-306. https://doi.org/10.1111/j.1540-6261.2005.00730.x

Petersen, M. A., \& Rajan, R. G. (2002). Does distance still matter? The information revolution in small business lending. The Journal of Finance, 57(6), 2533-2570. https://doi.org/10.1111/1540-6261.00505

Porta, R., Lopez-de Silanes, F., Schleifer, A., \& Vishny, W. R. (1997). Trust in large organizations. The American Economic Review, 87(2), 333-338. 


\section{Notes}

Note 1. India ranked 90th in the year 2005 according to the corruption perception index where it lagged behind countries like China, Mexico and Syria and has not improved remarkably until now.

Note 2. We further account for the respondents' occupation with a dummy variable "white-collar" that takes on the value of one if the respondent declares that he is employed in a formal professional or managerial position. The reference category is "other work", which refers to an occupation in the informal sector. In India, occupational status is often related to a certain bank type where the person has a bank account. Moreover, foreign banks often provide financial services to business customers. Hence, controlling for self-employment is very important. Moreover, we control for socio-demographic characteristics like age, gender or marital status.

Note 3. The variable "Foreign Bank to Private Bank Ratio" is calculated by dividing the total number of foreign banks per Indian state by the total number of private banks per Indian state.

Note 4. We computed variation inflation factors (VIFs) since multicollinearity might be an issue because we employ a large number of explanatory variables. The largest VIFs can be found for the education levels High School (3.16), higher secondary (4.33), and technical diploma (3.13). Since these values are below the critical value suggested in the literature, multicollinearity does not seem to be an issue.

Note 5. The dependent variable takes on the value one if the respondent trusts an Indian private bank more than a foreign bank (column (1)), it takes on the value 2 if trust in both types of banks is equal (column(2)), and the value is 3 if an individual trusts a foreign bank more than an Indian private bank (column(3)).

Note 6. The results of these robustness checks are available from the authors upon request.

\section{Copyrights}

Copyright for this article is retained by the author(s), with first publication rights granted to the journal.

This is an open-access article distributed under the terms and conditions of the Creative Commons Attribution license (http://creativecommons.org/licenses/by/4.0/). 